University of Nebraska - Lincoln

DigitalCommons@University of Nebraska - Lincoln

Faculty Publications: Department of Entomology

$2-1990$

Response to Selection for Virulence of Nephotettix virescens

(Homoptera: Cicadellidae) on Resistant Rice Cultivars

\author{
E. A. Heinrichs \\ H. R. Rapusas
}

Follow this and additional works at: https://digitalcommons.unl.edu/entomologyfacpub

Part of the Agriculture Commons, and the Entomology Commons

This Article is brought to you for free and open access by the Entomology, Department of at

DigitalCommons@University of Nebraska - Lincoln. It has been accepted for inclusion in Faculty Publications:

Department of Entomology by an authorized administrator of DigitalCommons@University of Nebraska - Lincoln. 

permission.

Submitted October 24, 1988; accepted April 21, 1989; published February 1, 1990.

\title{
Response to Selection for Virulence of Nephotettix virescens (Homoptera: Cicadellidae) on Resistant Rice Cultivars
}

\author{
E. A. Heinrichs* and H. R. Rapusas \\ Department of Entomology, The International Rice Research Institute, Manila, Philippines \\ * Current address - Department of Entomology, 402 Life Sciences Building, Louisiana State University, Baton \\ Rouge, LA 70803
}

\begin{abstract}
Rate of response to selection for Nephotettix virescens (Distant) virulence was studied for 20 generations on five rice cultivars with different levels of resistance. Rate of response to selection on all cultivars varied depending on the measurement criteria. Survival, growth, progeny production, and weight increased, and developmental period decreased, with selection time. Based on survival, the $N$. virescens population became highly virulent within one to four generations, whereas high virulence as measured by progeny production generally required more generations of selection. Virulence as measured by the ability to vector tungro virus also increased with selection time.
\end{abstract}

Keywords: Insecta, rice, leafhoppers, biotypes

The leafhopper Nephotettix virescens (Distant) is a major threat to rice, Oryza sativa L., production in south and southeast Asia because it is an efficient vector of tungro virus (Rivera \& Ou 1965). Because of the cost and lack of effectiveness of insecticides, $N$. virescensresistant rice cultivars have been bred and released for commercial cultivation.

Breeding for $N$. virescens resistance has been a major objective since the rice breeding program was established at the International Rice Research Institute in the early 1960s. "IR 8," the first cultivar released by the institute, has a moderate level of $N$. virescens resistance. 
"IR 8" was followed by the release of a number of other cultivars, of which "IR 36," also a moderately resistant cultivar, has been the most widely planted (IRRI 1983).

Evidence of biotypic differences between $N$. virescens populations was first observed in 1967 when the newly introduced cultivar "IR 8," which was resistant to N. virescens in the Philippines, was reported as susceptible in laboratory tests in Bangladesh (Karim \& Pathak 1982). However, selection for $N$. virescens virulence on a commercially grown cultivar had not yet been observed at that time.

"IR 36" was released in 1976, and in a few years occupied most of the lowland rice area in the Philippines. A survey in 1979 indicated that natural selection for a virulent population of N. virescens on "IR 36" had not occurred (Rapusas \& Heinrichs 1982). However, the survey was repeated in 1984 and indicated the presence of $N$. virescens populations virulent on "IR 36" in some locations (Rapusas \& Heinrichs 1986).

Because the commercial IR cultivars do not have resistance to tungro virus, selection for $N$. virescens virulence on resistant cultivars is expected to result in high tungro incidence. A study was conducted to determine the fitness of artificially selected $N$. virescens colonies based on feeding and development. The ability of the adults to transmit tungro virus in rice with different levels of $N$. virescens resistance also was examined (Heinrichs \& Rapusas 1984). The study indicated that after selection on highly resistant "Pankhari 203" and moderately resistant "IR 8," "Ptb 8," “TAPL 796," and "Moddai Karuppan" for 19 generations, survival increased and duration of the nymphal period decreased on all cultivars. However, there were distinct differences among cultivars in the percentage of tungro virusinfected plants that indicated possible differences in levels of tungro virus resistance.

In that study, the various parameters used to measure the level of $N$. virescens virulence were determined after the 19th generation of selection. By that time, selection had progressed to a level where $N$. virescens was as well adapted to the resistant cultivars as to the susceptible check "Taichung Native 1" ("TN 1"). Therefore, a follow-up study was conducted to determine the rate at which responses to selection occur on these same cultivars by measuring several parameters in generations 0 to 10 and in the 15th and 20th generations. The results of this study are reported herein.

\section{Materials and Methods}

About 100 pairs (males and females) of $N$. virescens adults were collected from each of 15 rice fields in different locations in the central and southern Philippines. All of the field collections were combined and were reared on "TN 1" in the greenhouse. To obtain N. virescens populations that had been reared on the respective test cultivars for various numbers of generations, the insects were transferred from "TN 1" to the cultivars on a staggered basis over time. The population to be tested after 20 generations of selection was transferred from "TN 1" to the test cultivars after two generations on "TN 1" and continuously reared on the respective cultivars for 20 generations. The population to be tested after 15 generations of selection on the test cultivars was transferred from "TN 1" to the test cultivars five generations after the transfer of the 20-generation population. This process was

continued until the generation-1 population was transferred. Separate cages each containing one of the following cultivars was established: "Pankhari 203" (Glh 1, gene for N. virescens 
resistance), "IR 8" (Glh 3 gene), "Ptb 8" (glh 4 gene), "TAPL 796" (Glh 6 gene), or "Moddai Karuppan" (Glh 7 gene). For each generation, 500 pairs of N. virescens were introduced into each cage. A single population was selected on each rice cultivar. Rearing cages were made of wood frames with nylon mesh sides and top and measured 50 by 50 by $10 \mathrm{~cm}$ (width, length, height).

Tests for levels of virulence for each generation from 0 to 10, 15, and 20 were conducted simultaneously. The parameters measured were adult recovery (survival of nymphs to the adult stage), developmental period, growth index, population growth, weight of adults, and efficiency in transmitting rice tungro virus. A colony that had been reared on susceptible "TN 1" for $>50$ generations was tested on "TN 1" and included as the control. In all tests, treatments were replicated five times and arranged in a randomized complete block design. Data were subjected to an analysis of variance $(P<0.05)$, and treatment means were separated using Duncan's (1955) multiple range test.

\section{Adult Recovery, Developmental Period, Growth Index, and Weight}

Five-day-old seedlings of the test cultivars were planted in clay pots $(5 \mathrm{~cm}$ diameter) at two seedlings per pot. Five pots were planted for each replication. Ten days later, the two plants in each pot were enclosed with one Mylar film cage $(4 \mathrm{~cm}$ diameter, $40 \mathrm{~cm}$ high), and pots were arranged in a metal tray half filled with water. At $20 \mathrm{~d}$ after sowing, the plants were infested by introducing two newly emerged $N$. virescens nymphs from the respective colony into each cage (10 insects per replication). The insects in each cage were observed daily. Emerging adults were counted, collected, placed in plastic vials, and weighed individually with a Mettler ME-30 electronic balance ( $1 \mu \mathrm{g}$ sensitivity) (Mettler Instrument Corporation, Hightstown, New Jersey).

The number of insects that survived to the adult stage and the length of developmental period (from infestation to adult emergence) were determined. Percentage of adult recovery (survivorship) was computed by the equation: number of adults counted/number of nymphs infested $\times 100$. The growth index was then computed by the equation: $\%$ adult recovery/mean developmental period (in days).

\section{Population growth}

Seven-day-old seedlings of the test cultivars were transplanted in clay pots $(10 \mathrm{~cm}$ diameter) with five seedlings per pot. One pot represented one replicate. One week after transplanting, the pots were arranged in a metal tray half filled with water, and the plants in each pot were enclosed with Mylar film cages (10 cm diameter, $90 \mathrm{~cm}$ high). When the plants were at 30 after sowing, they were infested by introducing into each cage five pairs of 3-d-old $N$. virescens adults coming from the respective colony. At $30 \mathrm{~d}$ after infestation, the hoppers in each cage were counted.

\section{Rice Tungro Virus Infection}

Five-day-old seedlings of the test cultivars were transplanted in clay pots $(5 \mathrm{~cm}$ diameter) at one seedling per pot. Five pots were planted for each replication. Pots were randomly arranged in a metal tray in the greenhouse, after which the plants in each pot were enclosed with a Mylar film cage ( $4 \mathrm{~cm}$ diameter, $40 \mathrm{~cm}$ high). Ten days after transplanting, the plants 
were inoculated with the virus by introducing a pair of viruliferous $N$. virescens adults into each cage. Viruliferous hoppers were obtained by allowing virus-free $N$. virescens adults to feed on tungro-infected "TN 1" plants for $48 \mathrm{~h}$. They were then allowed a 24-h inoculation period on the test cultivars. Twenty-five days after inoculation, tungro-infected plants were counted (based on visual damage symptoms), and percentage of tungro infection was computed by the equation: number of plants infected/number of plants inoculated $\times 100$.

\section{Results}

\section{"Pankhari 203"}

Adult recovery was low (18\%) in generation 0 (reared on "TN 1") but increased to $40 \%$ with just one generation of selection on "Pankhari 203" (Fig. 1). By generation 5, recovery was not significantly different from the control. The development period decreased from generation 3 to 5, being equal to the control in the fifth generation. The growth index was similar to the control by the sixth generation. Population growth was low (15 progeny per female) in generations 0 and 1. It took nine generations of selection before the population was not significantly different from that of the control. Both female and male weight decreased slightly in the second generation but increased thereafter. Female weight was equal to the control in the sixth, and male weight in the fifth generation. Except for a low percentage $(<10 \%)$ in generations 3 and 5, biotype selection did not result in a change in percentage of tungro-infected plants.

\section{"IR 8"}

Based on adult recovery, the "IR 8" colony took only three generations for virulence to develop (Fig. 2). The nymphal development period was longest in generation 1, then decreased gradually until generation 6. Developmental period from generations 6 to $20 \mathrm{did}$ not differ significantly from that of the control. Growth index was lowest in generations 0 and 1 , increased in generation 2, and continued to increase in generation 3 , when it did not differ significantly from that of the control. By the 15th generation, population growth was similar to that of the control.

Weight of female adults varied little among the generations except in generations 1 and

2 , which were significantly lower than the control. A similar trend also was observed in the weight of males, except those from generations 0 to 4 were lighter than the control.

The ability to transmit tungro virus increased with the increase in the number of generations through which the insects were reared on "IR 8" and equaled the control in generation 4 . Virus infection reached $100 \%$ in generation 15 .

\section{"Ptb 8"}

Adult recovery was high and similar to that of the control in all generations (Fig. 3). This parameter indicated an absence of resistance in 'Ptb 8.' Developmental period decreased with selection except in generation 15. Growth index was similar in all generations. Population growth fluctuated. Average weight of adults was similar in all generations. 
Biotype selection on "Ptb 8" significantly increased the efficiency of the insect to transmit tungro virus. Tungro infection was low (45-55\%) in generations 0 to 5 and increased to almost $100 \%$ in generation 6 and remained high to the 20th generation.

"TAPL 796"

Nymphs reared on "TN 1" and transferred to "TAPL 796" (0 generation) had 58\% adult recovery on "TAPL 796." Survival increased to almost $80 \%$ after one generation of selection on "TAPL 796" and remained high through generation 20 (Fig. 4). Developmental period fluctuated. Progeny per female was low until generation 10. Weight of adults, both male and female, increased significantly in generation 15.

Insects reared on "TN 1" (generation 0 ) were not able to transmit tungro virus to "TAPL 796." However, an increase in infection of $15 \%$ was observed from generations 1 to 3 . Tungro infection ranged from 45 to $65 \%$ in generations 6 to 20 , never reaching the control.

\section{"Moddai Karuppan"}

Adult recovery, developmental period, and growth index did not vary much among the various generations on "Moddai Karuppan" and the control (Fig. 5). Progeny production fluctuated. There was no significant increase in female and male weight until generations 15 and 20, respectively.

Tungro infection was initially high (65\% in generation 0$)$. This increased to $90 \%$ in generation 1 but decreased again in generation 2. Infection in generations 4-20 remained high (range, 82-100\%). 

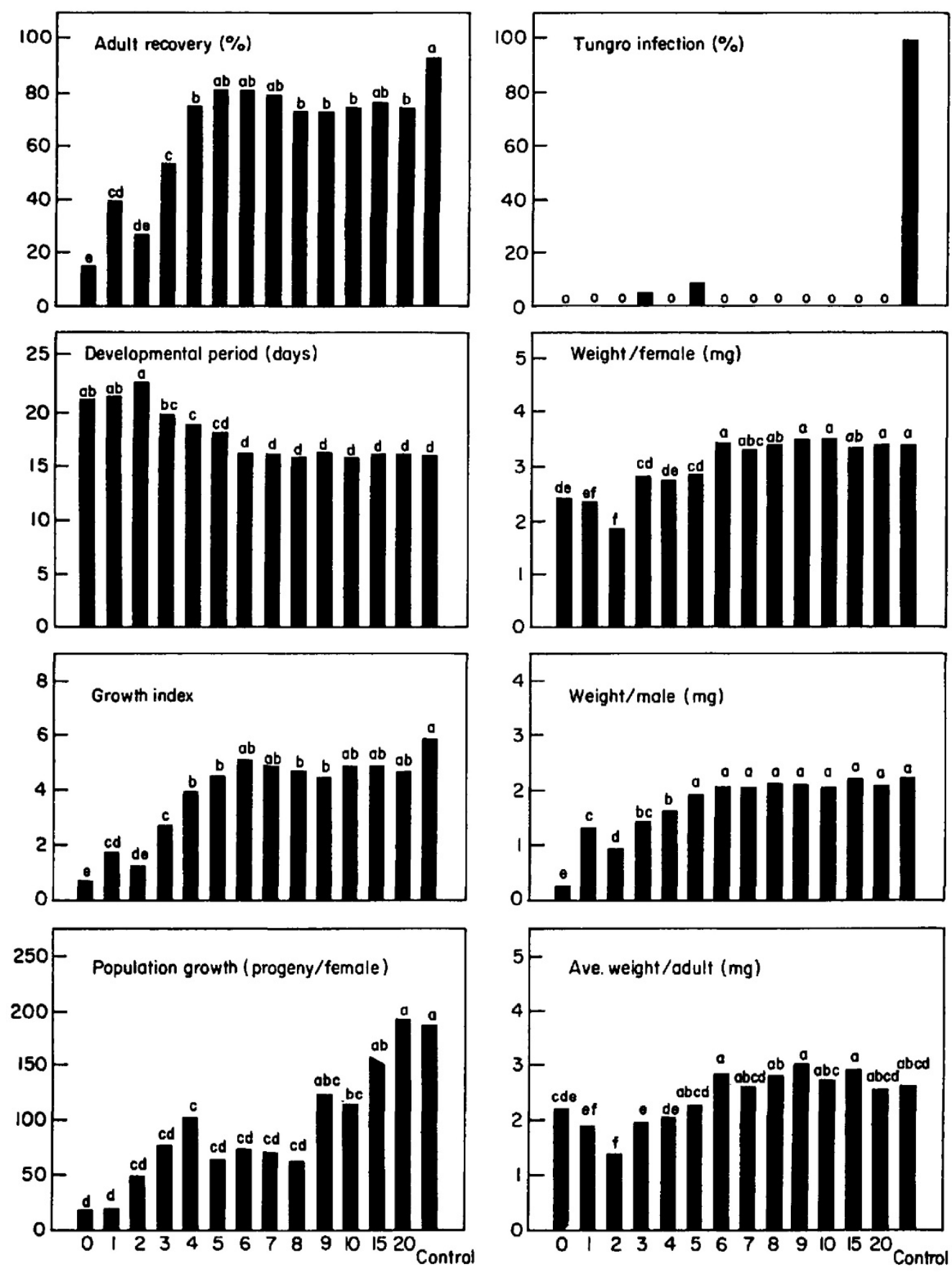

Generations

Figure 1. Percentage of adult recovery (survival), developmental period, growth index, population growth, tungro infection, weight of female and male adults, and average weight of adults of $N$. virescens reared on "Pankhari 203" for up to 20 generations and on susceptible "TN 1" (control). Bars within each parameter with the same letter are not significantly different $(P<0.05$, Duncan's (1955] multiple range test). 

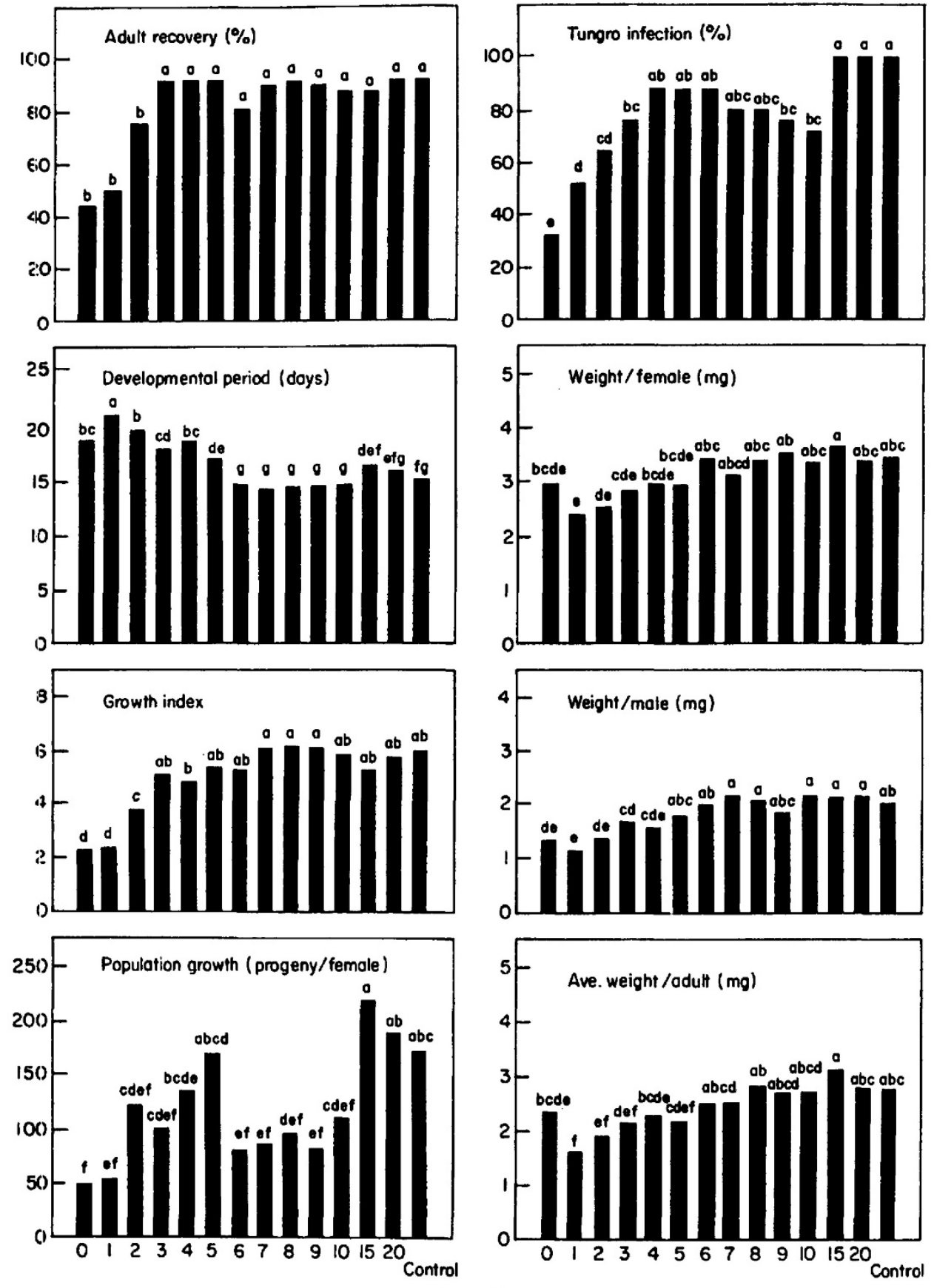

Generotions

Figure 2. Percentage of adult recovery (survival), developmental period, growth index, population growth, tungro infection, weight of female and male adults, and average weight of adults of $N$. virescens reared on "IR 8 " for up to 20 generations and on susceptible "TN 1" (control). Bars within each parameter with the same letter are not significantly different ( $P<0.05$, Duncan's [1955] multiple range test). 

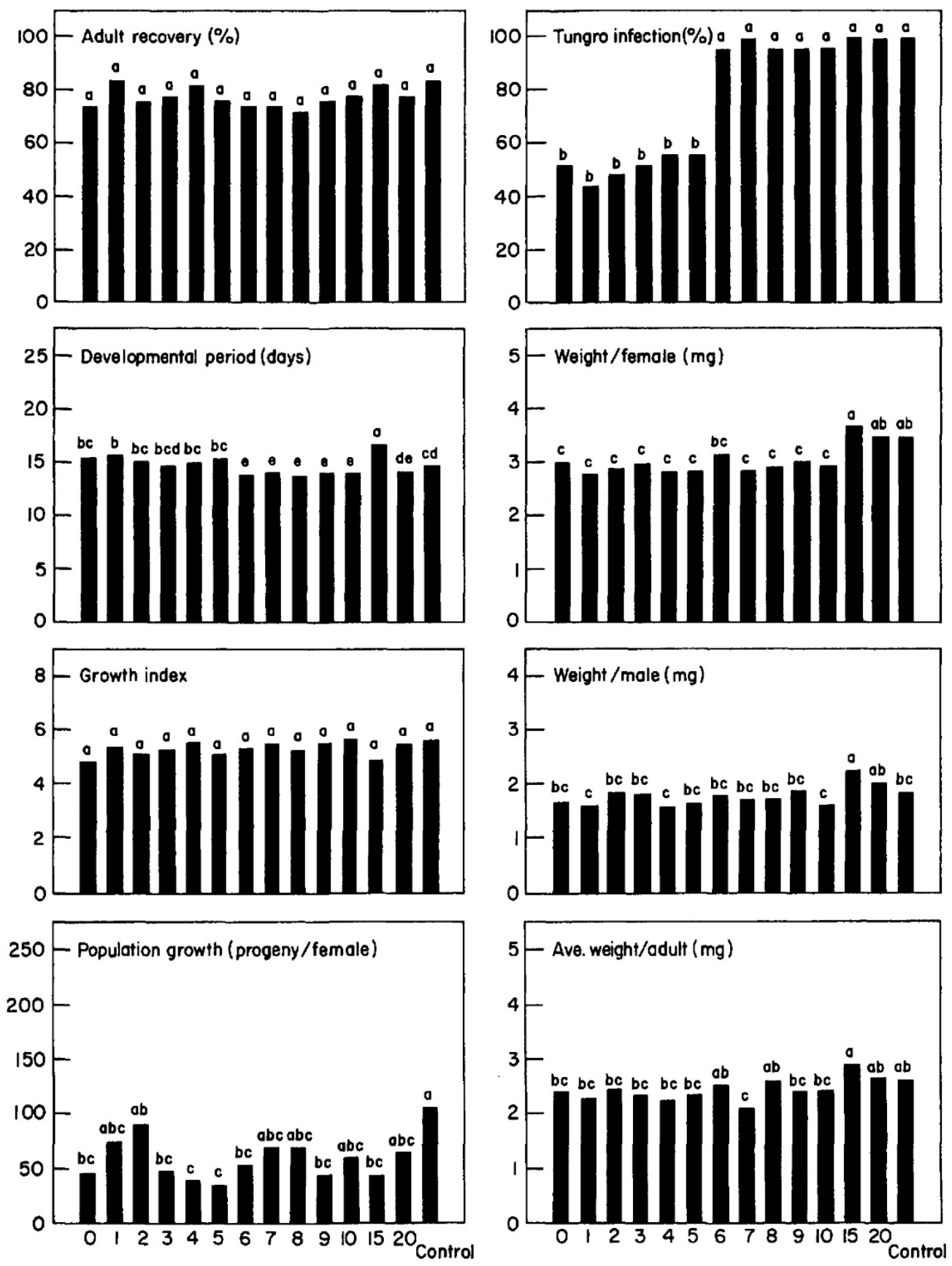

Generations

Figure 3. Percentage of adult recovery (survival), developmental period, growth index, population growth, tungro infection, weight of female and male adults, and average weight of adults of $N$. virescens reared on "Ptb 8 " for up to 20 generations and on susceptible "TN 1" (control). Bars within each parameter with the same letter are not significantly different $(P<0.05$, Duncan's [1955] multiple range test). 

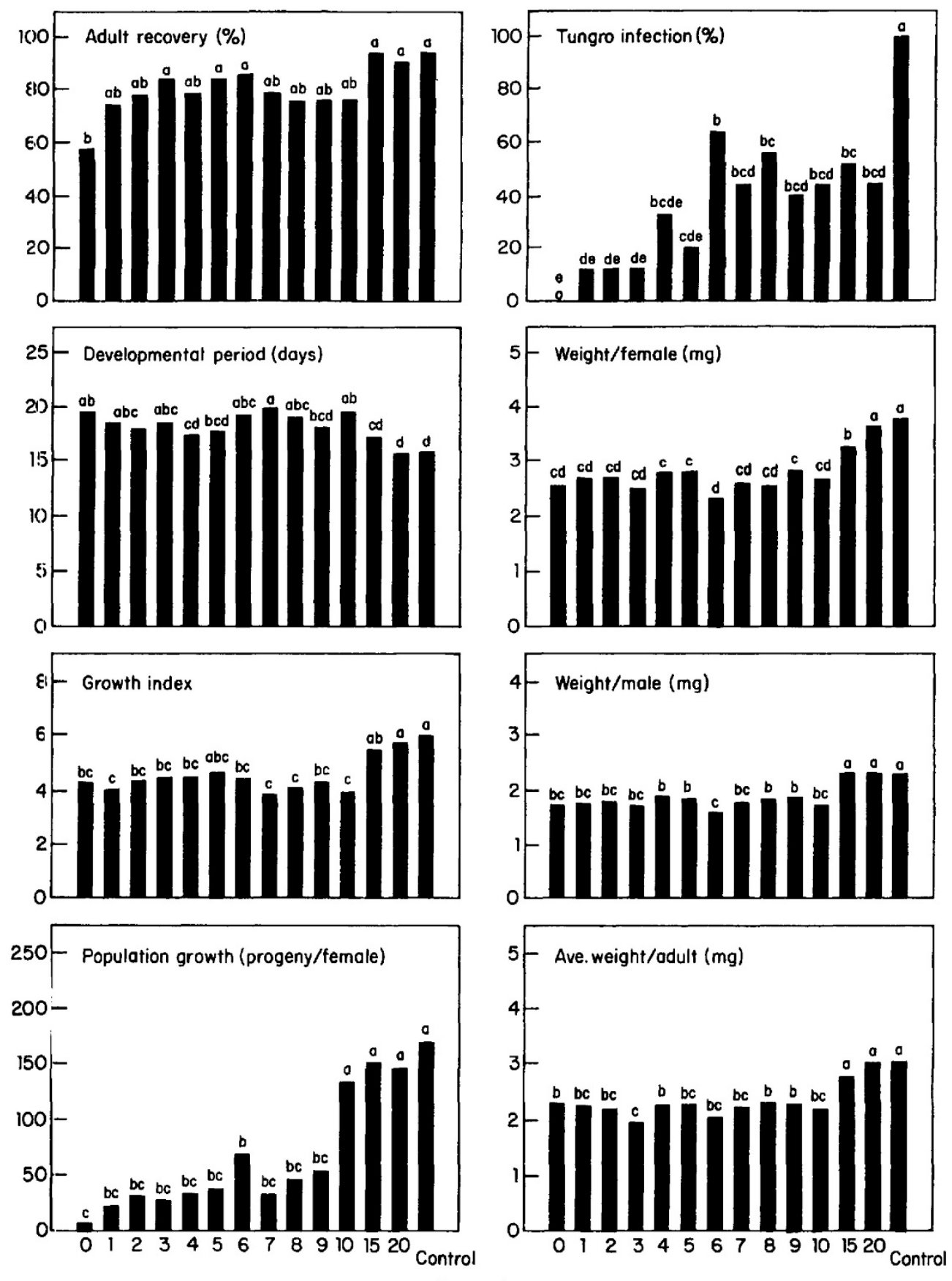

Figure 4. Percentage of adult recovery (survival), developmental period, growth index, population growth, tungro infection, weight of female and male adults, and average weight of adults of $N$. virescens reared on "TAPL 796" for up to 20 generations and on susceptible "TN 1" (control). Bars within each parameter with the same letter are not significantly different $(P<0.05$, Duncan's [1955] multiple range test). 

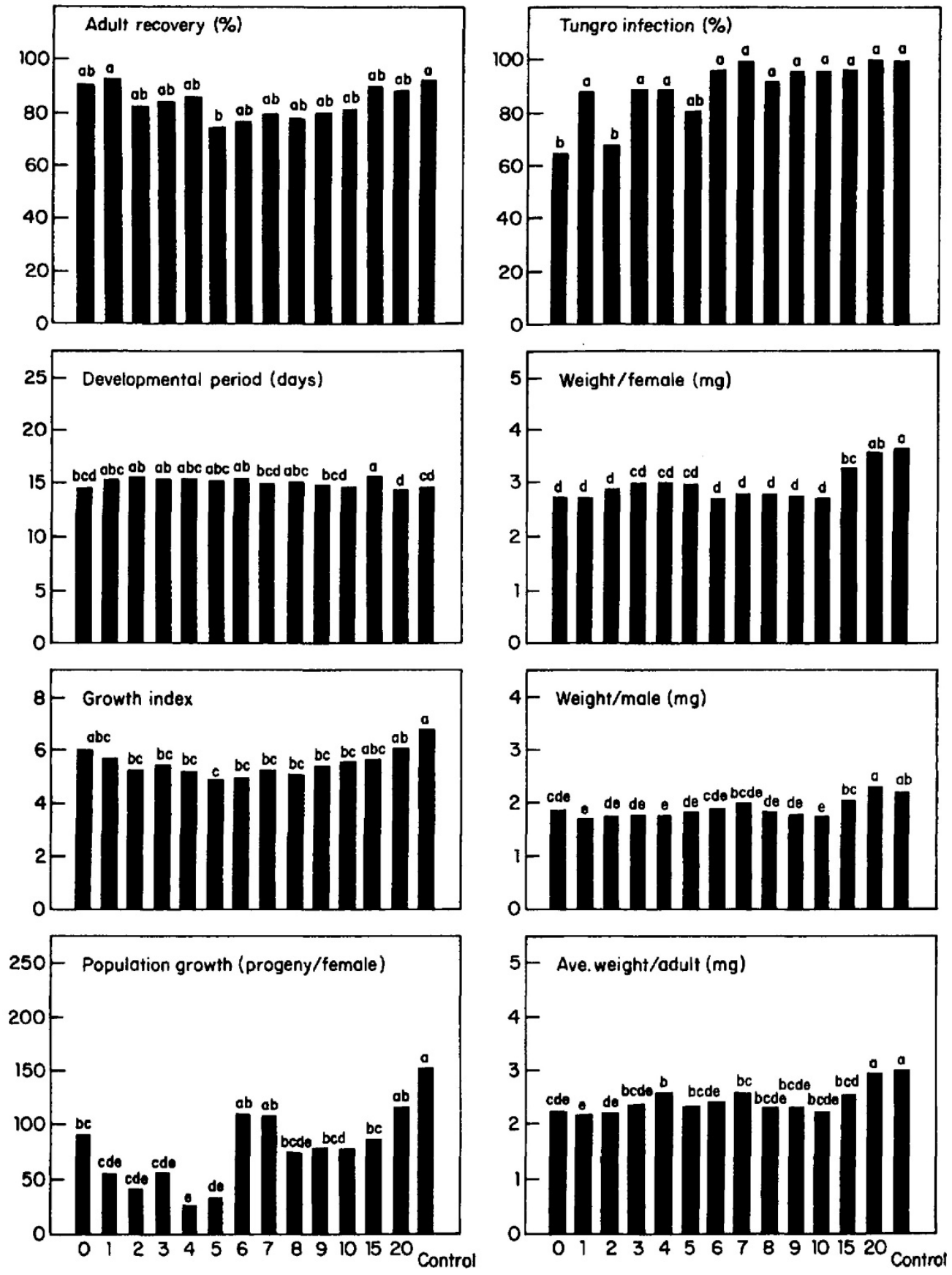

Generations

Figure 5. Percentage of adult recovery (survival), developmental period, growth index, population growth, tungro infection, weight of female and male adults, and average weight of adults of $N$. virescens reared on "Moddai Karuppan" for up to 20 generations and on susceptible "TN 1" (control). Bars within each parameter with the same letter are not significantly different $(P<0.05$, Duncan's [1955] multiple range test). 


\section{Discussion}

Selection of $N$. virescens on resistant cultivars is manifested by an increase in the survival, growth index, progeny production, weight, and a subsequent decrease in the period of development from the nymph to the adult stage. As this study indicated, the rate of selection for virulence to some extent varies with the level of $N$. virescens resistance in the cultivar on which the population is selected and depends on the criteria that are being used to measure virulence.

The five test cultivars differed in their level of resistance to $N$. virescens as indicated by their response in generation 0 (before selection). Differences were most obvious in adult recovery, where it was 18, 45, 75, 59, and 92\% on "Pankhari 203," "IR 8," "Ptb 8," "Moddai Karuppan," and "TAPL 796," respectively (Figs. 1-5). Selection for survival to the adult stage (adult recovery) occurs at a more rapid rate than does the ability to produce progeny. For example, survival of the population selected on "TAPL 796" was already similar to that of the susceptible control in generation 1, whereas population growth on "TAPL 796" did not reach the level of the control until generation 10 (Fig. 4). Insect weight also increased at a slower rate than did survival.

Percentage of tungro virus-infected plants is a function of the level of resistance of the cultivar to $N$. virescens and the level of resistance to the virus. Percentage of infection in generation 0 (unselected) was 0\% in "Pankhari 203" and "TAPL 796" and ranged from 35 to $65 \%$ in the other three test cultivars. In all cultivars except "Pankhari 203," there was an increase in the percentage of tungro virus-infected plants with selection time. It appears that the resistance of "TAPL 796" to N. virescens in generation 0 protected it from tungro infection, and as the resistance decreased with selection time, tungro infection subsequently increased. "Pankhari 203," however, apparently has resistance both to the vector and to the virus; when the resistance to the vector is lost, it continues to remain free of virus because of its resistance to the pathogen.

It is not known how the rates of response to selection in the laboratory for a given cultivar compares with the response rate to selection under field conditions. It should be noted that, although the response to selection was rapid in this study, it is not expected to occur at such a rapid rate under field conditions because of less selection pressure (i.e., alternative host plants such as weeds and susceptible rice cultivars). There is, however, evidence that after several years of commercial production in the Philippines, $N$. virescens virulence has increased on the extensively grown rice cultivars "IR 36" and "IR 42" (Rapusas \& Heinrichs 1986).

$N$. virescens is a major threat to rice production in Asia because of its efficiency as a tungro virus vector. Because tungro virus-resistant rice cultivars have not been identified, the major emphasis in breeding for tungro control has been on resistance to the vector, $N$. virescens. However, it is important to breed rice cultivars for resistance to both $N$. virescens and tungro virus so that if the insect resistance is lost because of an increase in the level of vector virulence, the virus resistance will still be able to protect the plant from infection. For this purpose, the genetic evaluation program of the International Rice Research Institute has increased its screening activities to identify tungro-resistant cultivars suitable for use in the breeding program. 


\section{References Cited}

Duncan, D. B. 1955. Multiple range and multiple F tests. Biometrics 11: 1-42.

Heinrichs, E. A. \& H. R. Rapusas. 1984. Feeding, development, and tungro transmission by the green leafhopper, Nephotettix virescens (Distant) (Homoptera: Cicadellidae) after selection on resistant rice cultivars. Environ. Entomol. 13: 1074-1078.

International Rice Research Institute (IRRI). 1983. IR36, the world's most popular rice. International Rice Research Institute, Los Baños, Philippines.

Karim, A. N. M. Rezaul \& M. D. Pathak. 1982. New genes for resistance to green leafhopper, Nephotettix virescens (Distant), in rice, Oryza sativa L. Crop Prot. 1: 483-490.

Rapusas, H. R. \& E. A. Heinrichs. 1982. Comparative virulence of 15 cultures of green leafhopper, Nephotettix virescens (Distant), on selected varieties. Philipp. Entomol. 5: 213-226.

Rapusas, H. R. \& E. A. Heinrichs. 1986. Virulence of green leafhopper (GLH) colonies from Luzon, Philippines, on IR36 and IR42. Int. Rice Res. Newsl. 11(1): 15.

Rivera, C. T. \& S. H. Ou. 1965. Leafhopper transmission of tungro disease of rice. Plant Dis. Rep. 49: $127-131$. 